\title{
Agro-industrial wastes as sources of bioactive compounds for food and fermentation industries
}

\author{
Ligianne Din Shirahigue ${ }^{1}$ Sandra Regina Ceccato-Antonini ${ }^{12^{*}}$ (D)
}

\footnotetext{
${ }^{1}$ Programa de Pós-graduação em Produção Vegetal e Bioprocessos Associados (PPG-PVBA), Universidade Federal de São Carlos (UFSCar), Araras, SP, Brasil.

${ }^{2}$ Departamento de Tecnologia Agroindustrial e Sócio-Economia Rural, Centro de Ciências Agrárias, Universidade Federal de São Carlos (UFSCar), 13600-970, Araras, SP, Brasil. E-mail: antonini@ufscar.br. *Corresponding author.
}

\begin{abstract}
Agro-industrial wastes are of great interest because they are important natural sources of bioactive compounds and can generate value-added byproducts. Recent studies have shown that byproducts generated by the food processing industry are rich in bioactive compounds, such as phenolic compounds, organic acids, and carotenoids, among others. The growing interest in replacing synthetic antioxidant and antimicrobial compounds with natural ones has stimulated a search for these bioactive compounds from plant sources, especially from fruitprocessing wastes. The study aims to project the agro-industrial wastes as potential natural sources of antioxidants and antimicrobials and the feasible technological applications in food and fermentation industries, especially the bioethanol industry.

Key words: phenolic compounds, antioxidant activity, antimicrobial activity, agro-industrial waste.
\end{abstract}

Resíduos agroindustriais como fontes de compostos bioativos para as indústrias de alimentos e de fermentação

RESUMO: Residuos agroindustriais são de grande interesse por serem importantes fontes naturais de compostos bioativos e assim gerar subprodutos de valor agregado. Estudos recentes mostraram que o processamento de alimentos gera subprodutos ricos em compostos bioativos tais como compostos fenólicos, ácidos orgânicos e carotenóides, entre outros. O crescente interesse em substituir compostos antioxidantes e antimicrobianos sintéticos por naturais tem estimulado a procura por esses compostos bioativos a partir de fontes vegetais, especialmente de resíduos de processamento de frutas. O objetivo desta revisão é destacar os resíduos agroindustriais como potenciais fontes naturais de antioxidantes e antimicrobianos assim como as possíveis aplicações tecnológicas nas indústrias de alimentos e de fermentação, especialmente a indústria do bioetanol.

Palavras-chave: compostos fenólicos, atividade antioxidante, atividade antimicrobiana, resíduo agroindustrial.

\section{INTRODUCTION}

The production of primary and secondary metabolites is a characteristic property of living organisms that could be utilized for pharmacological and technological purposes. These chemical compounds are called "natural products." Besides their pharmaceutical actions on humans, they also possess biological activity. Natural antimicrobials are secondary metabolites, which possess antimicrobial activity, and are extracted from different sources such as plants, animals, and microorganisms. Besides this, these secondary metabolites also contain the property of antioxidants, and therefore, are considered a prospective option for food preservation in contrast to synthetic preservatives (ARSHAD \& BATOOL, 2017).

The valuable sources of these natural products with antimicrobial and antioxidant properties are the residues resulting from the agro-industrial processes, which may contribute to a significant pollution problem in lack of proper management. With no viable alternatives, they are often discarded directly into the surrounding environment. Apart from a considerable loss of valuable materials, the large amount of wastes produced by agro-industries also raises serious management problems, both from economic and environmental points of view (MIRABELLA et al., 2014). Many of these wastes, however, can potentially be used in other production 
systems, such as the production of natural food additives. Research on the composition and characterization of the generated wastes has been carried out with the objective that the waste residues can be put to value-added applications with possible technology (VIEIRA et al., 2009). Sustainable applications of the waste products (as alternatively called "byproducts") include production of organic fertilizers, animal feeds, ethanol, enzymes, essential oils, and additives in various technological processes (FERRARI et al., 2004; KOBORI \& JORGE, 2005; ALEXANDRINO et al., 2007; RODRIGUES et al., 2009; LIU et al., 2012). It is also observed that plant foods and their food processing byproducts are the potential source of phenolic bioactive compounds that have valuable health benefits (CAMARGO et al., 2018).

Initially, interest was focused on the study of substances possessing antioxidant and antimicrobial activities that emerged from the search for new additives, which could be used in place of the synthetic ones already being used in technological processes. Synthetic additives alter enzymes and lipids in humans and animals and have a potential carcinogenic effect (ROCHA et al., 2007). Thus, recent research has been conducted to replace chemical additives by non-synthetic ones that can be produced from agro-industrial wastes. The growing interest for natural antioxidant and antimicrobial compounds has led to research on plants as a source of such bioactive compounds (MOURE et al., 2001; SHAKER, 2006; CARPENTER et al., 2007; OLIVEIRA et al., 2009; SASSE et al., 2009; BREWER, 2011; SHIRAHIGUE et al.., 2011; BABBAR et al., 2011; LOPES et al., 2013; ARBOS et al., 2013; CAMARGO et al., 2014; SILVA \& JORGE, 2014; CAMARGO et al., 2018; SERRANO-LEÓN et al., 2018).

In this review, we aimed to project the agro-industrial wastes as potential natural sources of antioxidants and antimicrobials and explored their possible technological applications in the food and fermentation industry.

\section{Bioactive compounds: application as antioxidants and antimicrobials}

Bioactive compounds are defined as substances with biological activity and are able to modulate metabolic processes resulting in the promotion of better health conditions. The benefits exhibited by these compounds include antioxidant activity, inhibition or induction of enzymes, inhibition of receptor activities, and induction and inhibition of gene expression (CORREIA et al., 2012). Fruits, vegetables, and whole grains are good sources of bioactive compounds, which include a heterogeneous class of compounds mainly phenolics, carotenoids, tocopherols, phytosterols, and organosulfur compounds (CARBONELL-CAPELLA et al., 2013; SERRANO-LEÓN et al., 2018) (Figure 1).

The secondary metabolites produced by plants such as flavonoids, thiosulfinates, glucosinolates, organic acids, and saponins are antimicrobial agents used against a great variety of microorganisms. The most important group of compounds with antimicrobial activity is phenolics, which include terpenes, aliphatic alcohols, aldehydes, ketones, acids, anthocyanins, and isoflavonoids (SPANOS \& WROLSTAD, 1992; BURT, 2004; ARSHAD \& BATOOL, 2017). Phenolic compounds are widely distributed in nature and are the most abundant secondary metabolites reported in plants (MAXCHEIX et al., 1990). The primary action of phenolics is related to the plant defense against biotic and abiotic stresses, pests, and pathogens (ATANASOVA-PENICHON et al., 2016; ZHANG \& TSAO, 2016; CAMARGO et al., 2018).

Flavonoids are a large group of phenolic compounds reported in various fruits, vegetables, roots, etc. (MIDDLETON \& KANDASWAMI, 1994; HOLLMAN \& KATAN, 1997). The monomeric units of these compounds consist of two substituted benzene rings (A and $\mathrm{B}$ ) and, in most cases, a heterocyclic ring (C) (HOLLMAN et al., 1996). More than 4,000 compounds of flavonoids have been identified (JAYAPRAKASHA et al., 2003). The different substitutions in rings $\mathrm{A}, \mathrm{B}$, and $\mathrm{C}$, as well as the different ways in which ring $B$ is bound to ring $\mathrm{C}$, allow the formation of several types of flavonoids with different biological characteristics. Flavonoids consist of different subclasses as illustrated in Figure 1: flavanones, flavonols, flavones, flavanols (or flavan-3-ols), isoflavones and anthocyanidins (HE \& GIUSTI, 2010; OLIVEIRA et al., 2014). They occur in various foods, such as anthocyanidins in grape, wine, cherries, and eggplant peel; flavonols in onion, broccoli, kale, apple peel, tea, and grape; flavones in sorghum, lemon, red pepper, and parsley; flavanols in apple skin, banana, berries, Camelia sinensis teas; isoflavonoids in soybean and soy products; and flavanones in citrus fruit and tomato skin, as some examples, many of them with antioxidant and antimicrobial activities (RICE-EVANS et al., 1996; HOLLMAN \& KATAN, 1997; OLIVEIRA et al., 2014; XU et al., 2017). The highest activities are displayed by the class of flavanols, especially the procyanidin group and catechins, epicatechins, and their esterified derivatives.

Within the phenolics, non-flavonoids comprise phenolic acids, tannins, stilbenes and 


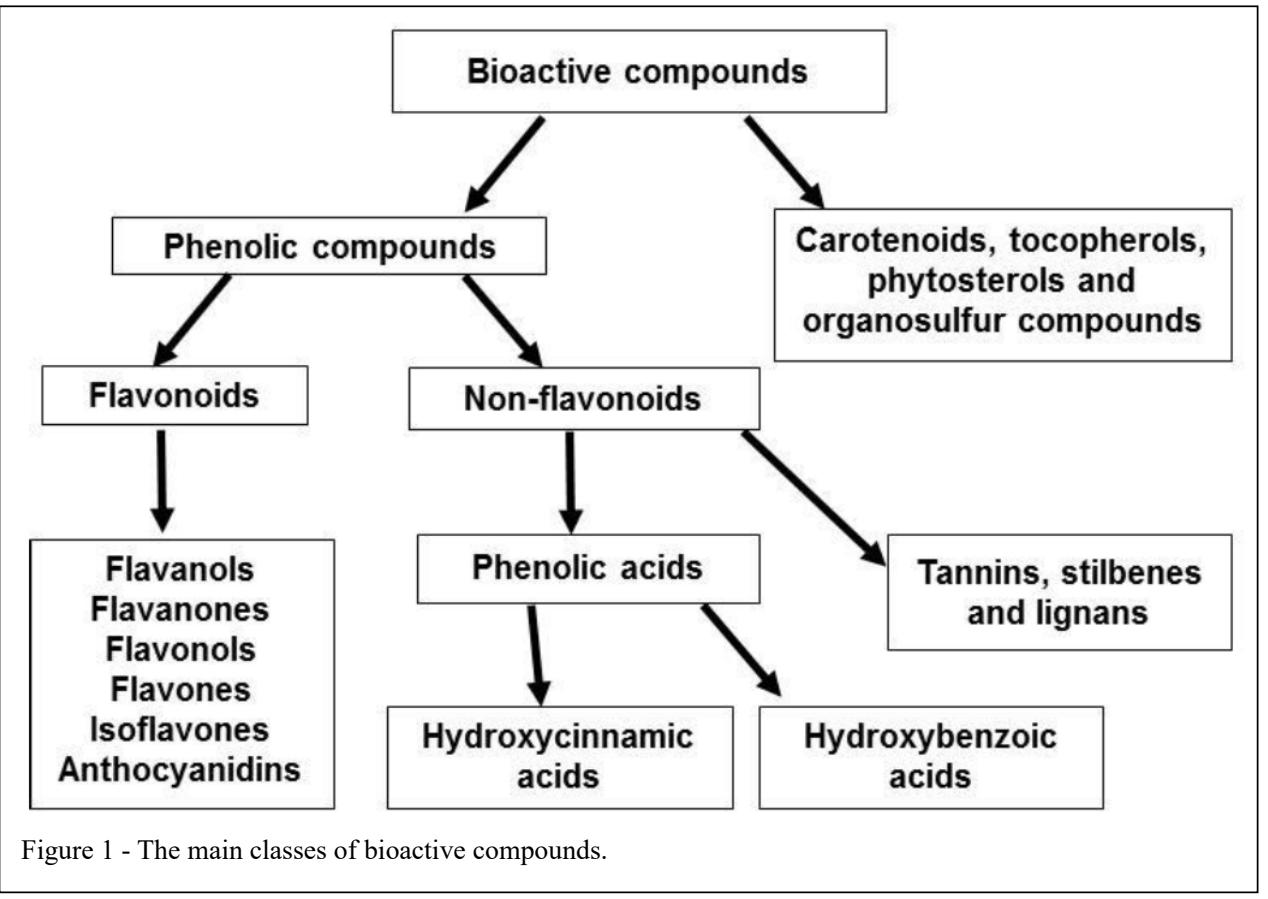

lignans. Phenolic acids are widely spread throughout the plant kingdom and their effects have been ascribed to their antioxidant, antimutagenic, anticarcinogenic, antimicrobial, and other biological properties (XU et al., 2008). Substituted derivatives of hydroxybenzoic and hydroxycinnamic acids are the predominant phenolic acids. The most common hydroxycinnamic acids are caffeic, p-coumaric, and ferulic acids, which frequently occur in food as simple esters with quinic acid or glucose (SHAHIDI \& AMBIGAIPALAN, 2015), while the most common benzoic acid is gallic acid, occurring in red fruits, onions and black radish (XU et al., 2017).

Tannins are water-soluble polyphenols commonly presented as hydrolysable tannins or condensed tannins, the latter are the most common, consisting of two or more monomeric $(+)$-catechin or (-)-epicatechin units. Tannins are able to bind and precipitate proteins and other macromolecules in aqueous solutions, to bind metals and form blue to black complexes with iron salts, with molecular weight ranging from 500 to 3,000 daltons (SALMINEN \& KARONEN, 2011). The most known stilbene is resveratrol, which is reported in vine plant, peanut and berries, and extensively studied for its multiple bioactivities (XU et al., 2017). Lignans are present in seeds, vegetable oils, cereals, legumes, fruits and vegetables, displaying an enormous structural diversity. The most common lignans are lariciresinol, pinoresinol, secoisolariciresinol, syringaresinol, matairesinol, 7-hydroxymatairesinol, sesamin, sesamolin and sesamol (GERSTENMEYER et al., 2013).

The great diversity of bioactive compounds reported in plant processing residues encourages the search for natural antioxidants for application in food and drug industries. According to the FDA (Food and Drug Administration), antioxidants are substances used to preserve food by retarding deterioration through rancidity or discoloration that is caused by the oxidation process (DZIEZAK, 1986). These are compounds present in small amounts with a primary function of preserving or retarding oil and fat oxidations (POKORNY, 1991). These substances may have originated from commercial sources and naturally isolated compounds from foods (ADEGOKE et al., 1998). An essential requirement for the use of an antioxidant in food requires it to be efficient at low concentrations, compatible with the substrate, sensory acceptability, non-toxicity, and protection of the food from the deleterious effects of oxidation (SCHULER, 1990).

An antioxidant functions in various ways: competitively binding to oxygen, delaying the initiation step, and/or inhibiting the propagation step by destroying or binding free radicals or inhibiting the catalysts and stabilizing the hydroperoxides (ALLEN \& HAMILTON, 1994). The antioxidant may act on the 
cell membranes to protect food by: (1) sequestering free radicals and not starting the oxidation process; (2) inactivating metallic ions; (3) removing oxygen reactive species; (4) sequestering single oxygen; (5) destroying peroxides and preventing formation of radicals; and (6) removing and/or decreasing the local oxygen concentration (DZIEZAK, 1986).

Due to the potential risks of synthetic antioxidants to human health, much interest has been developed in natural sources of these compounds to reduce or delay oxidation processes on food in recent years (AHN et al., 1998; JAYAPRAKASHA et al., 2001; MOURE et al. 2001; BREWER, 2011). Natural antioxidants are molecules present in plants, in small amounts, which inhibit the oxidation process that produces free radicals. Natural antioxidants have the ability to reduce the rate of oxidation of the lipid compounds present in certain dietary products. These antioxidant compounds include flavonoids, phenolic acids, carotenoids, and tocopherols (KHANDUJA \& BHARDWAJ, 2003; OZSOY et al., 2009).

The antioxidant potential of the bioactive compounds depends on the number and arrangement of the hydroxyl groups. These compounds can donate hydrogen atoms to lipid radicals and produce lipid derivatives and antioxidant radicals, which are more stable and less readily available to promote autoxidation (SHAHIDI \& AMBIGAIPALAN, 2015).

Plants are the main sources of natural antimicrobials, i.e., compounds capable of inhibiting the growth of microorganisms. They can be used along with older antibiotics to increase their potency to avoid the development of microbial resistance. The plant compounds that are extensively utilized for antimicrobial purposes comprise alkaloids, sulfur-containing compounds, terpenoids, and phenolic compounds (KHAMENEH et al., 2019). Thus far, more than 1,350 plants with antimicrobial activities and more than 30,000 antimicrobial substances extracted from plants have been reported (TAJKARIMI et al., 2010). Plants are a big bet as sources of natural antimicrobials, and in this sense, the utilization of plant parts normally discarded as wastes arises as a sustainable and safe option in the search for novel antimicrobial agents.

\section{Agro-industrial wastes as sources of bioactive compounds}

The agro-industrial products from food industries produce a large amount of vegetable and fruit wastes, which affect municipal landfills. Despite being highly biodegradable, these generate leachate and are responsible for methane emission (MISI $\&$ FORSTER, 2002). These wastes are generated by different processes and contain an appreciable amount of bark, seeds, and other types of plant components. These waste components serve as a source of proteins, enzymes, essential oils, and other compounds with biological activity that can be recovered and used. The processing of food from vegetable origin results in production of byproducts that are rich sources of bioactive compounds (SCHIEBER et al., 2001) (Figure 2). The availability of these compounds in the agroindustry residue will depend on the mode of extraction, type of solvent, and purification (SOQUETTA et al., 2018). A general scheme to obtain extracts from different parts of the plants is shown in figure 3 .

Antioxidant and antimicrobial activities have been reported in several agricultural products (BALASUNDRAM et al., 2006). DENG et al. (2012) evaluated the potential of wastes from 50 fruits (peel and seed) as resources of bioactive compounds and demonstrated that the antioxidant potential was higher in residues than in pulps. A large group of bioactive compounds was identified such as catechin, cyanidin 3-glucoside, epicatechin, galangin, gallic acid, homogentisic acid, kaempferol, and chlorogenic acid.

Tables 1 to 4 list the studies that used agroindustrial residues as natural sources of antioxidants and antimicrobials and summarize the main results and technological applications.

\section{Wastes from fruit processing: rich sources of bioactive compounds with technological applications}

\section{Grape}

Grape (Vitis vinifera) seed extracts are obtained as the byproducts of wine-making or grape juice and are rich in proanthocyanidins (condensed tannins) and other phenolic compounds (RABABAH et al., 2004; MIELNIK et al., 2006; WEBER et al., 2007). Phenolic compounds in grape and grape products can be divided into two groups, non-flavonoids and flavonoids. The most common phenolic acids found in grape include cinnamic acids (coumaric acid, caffeic acid, ferulic acid, chlorogenic acid, and neochlorogenic acid) and benzoic acids (p-hydroxybenzoic acid, vanillic acid, and gallic acid). Flavonoids include flavan-3-ols (catechin, epicatechin polymer and ester with galactic acid or glucose), flavonols (quercetin) and red and blue anthocyanins (SHI et al., 2003; SHAHIDI \& AMBIGAIPALAN, 2015). Studies have shown that grape seeds are rich sources of monomeric 


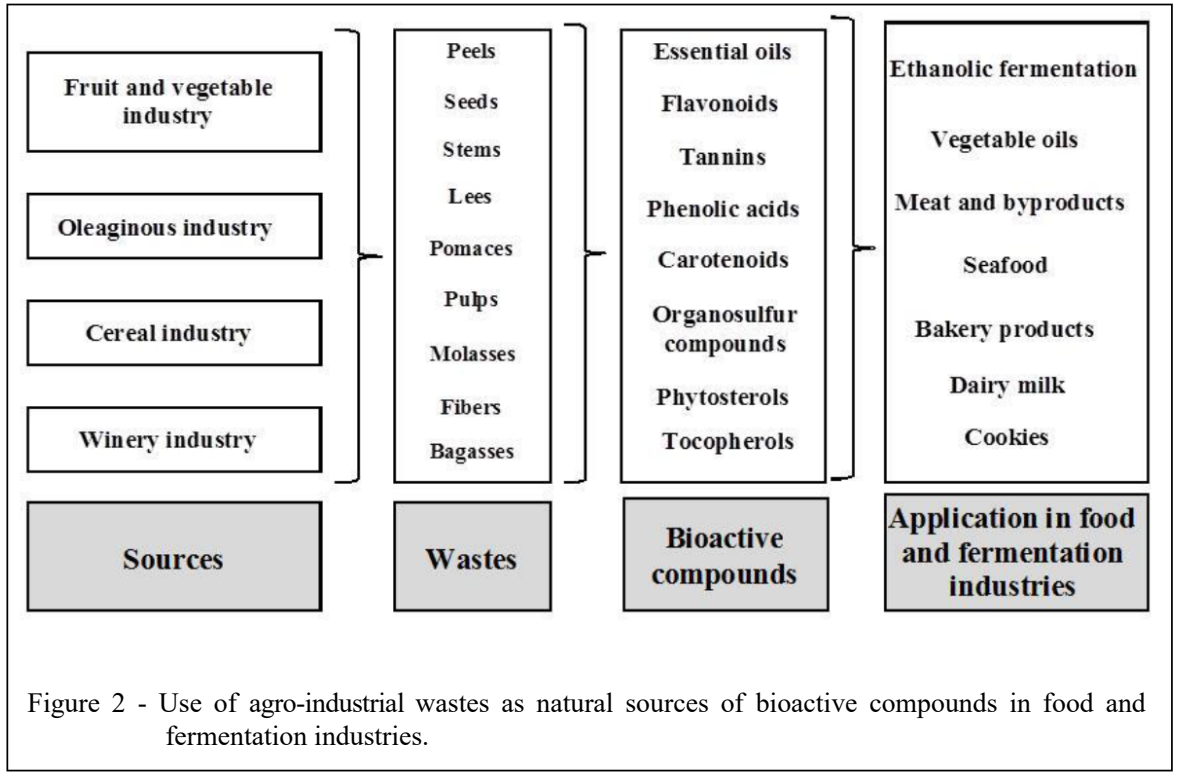

phenolics such as (+)-catechins, (-)-epicatechin, $(+)$-gallocatechins, (-)-epigallocatechin, and their dimeric, trimeric, and tetrameric proanthocyanidins (SHAHIDI \& AMBIGAIPALAN, 2015).
The utilization of wastes produced from the wine industry as natural antioxidants has been extensively studied in various types of raw material, such as beef, chicken, pork, and turkey, by means

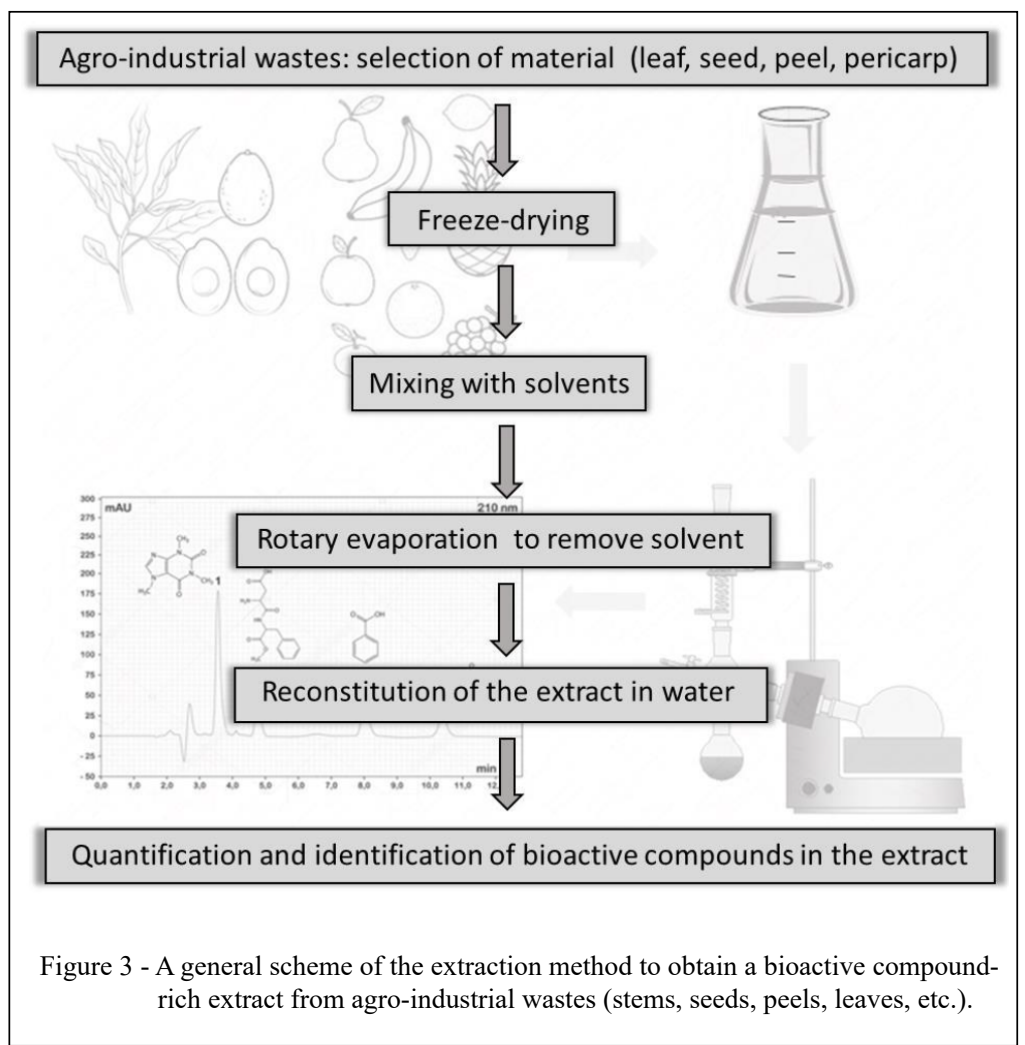

Ciência Rural, v.50, n.4, 2020. 
Table 1 - Agro-industrial residues as natural sources of antioxidants and antimicrobials, the main results of the study, and the technological applications of the wastes - PART I.

\begin{tabular}{|c|c|}
\hline Sources & Main results and applications \\
\hline $\begin{array}{l}\text { Avocado peel, } \\
\text { kernel, and pulp }\end{array}$ & $\begin{array}{l}\text { Avocado byproducts presented a very distinct phenolic profile. Higher concentration in peels, mainly } \\
\text { epicatechin derivates followed by chlorogenic derivates (MELGAR et al., 2018). }\end{array}$ \\
\hline $\begin{array}{l}\text { Avocado seed fatty } \\
\text { acid derivatives }\end{array}$ & $\begin{array}{l}\text { The study describes the antilisterial potential of an enriched acetogenin extract from avocado seeds. Seeds } \\
\text { contained } 1.6 \text { times higher acetomigenin levels than pulp. Results strengthen the potential of avocado } \\
\text { acetogenins, especially from avocado seed, as a source of natural antimicrobial food additives (SALINAS- } \\
\text { SALAZAR et al., 2017). }\end{array}$ \\
\hline $\begin{array}{l}\text { Crude epicarp and } \\
\text { seed extract from } \\
\text { avocado fruits }\end{array}$ & $\begin{array}{l}\text { The ethanolic extracts showed antimicrobial activity toward both Gram-positive and Gram-negative bacteria } \\
\text { (except Escherichia coli), while inhibition of the water extracts was only observed for Listeria monocytogenes } \\
\text { and Staphylococcus epidermidis. The crude extracts of the epicarp and seed of mature avocados contain } \\
\text { antimicrobials and show the potential to be used as food additives (CHIA \& DYKES, 2010). }\end{array}$ \\
\hline Acerola peel & $\begin{array}{l}\text { The acerola peel extract exhibited high total phenolic content. DPPH (2,2-Diphenyl-1-picrylhydrazil) } \\
\text { scavenging capacity of acerola waste was }>70 \% \text { and it can be considered as a promising source of natural } \\
\text { antioxidants (CAETANO et al., 2009). }\end{array}$ \\
\hline $\begin{array}{l}\text { Acerola bagasse } \\
\text { flour }\end{array}$ & $\begin{array}{l}\text { In the extract, phenolic compounds were identified in the following order of increasing concentration: } \\
\text { quercetin, p-coumaric acid, gallic acid, epigallocatechin gallate, catechin, syringic acid, and epicatechin. It } \\
\text { showed antioxidant potential and bactericidal activity for both Gram-negative and Gram-positive strains, } \\
\text { presenting the potential to be used in the food industry (MARQUES et al., 2017). }\end{array}$ \\
\hline $\begin{array}{l}\text { Mango, pineapple } \\
\text { and passion fruit } \\
\text { byproducts }\end{array}$ & $\begin{array}{l}\text { The fruit byproducts have the potential to be used as functional ingredients, providing dietary fiber (for } \\
\text { nutritional and technological purposes) and natural antioxidants to foods (SELANI et al., 2016). }\end{array}$ \\
\hline Mango seed & $\begin{array}{l}\text { Mango seed is a potential source of nutritional food ingredients due to the high quality of fat and proteins and } \\
\text { the high content of compounds with antioxidant and antimicrobial activities (TORRES-LEON et al., 2016). }\end{array}$ \\
\hline $\begin{array}{l}\text { Mango peel and } \\
\text { kernel }\end{array}$ & $\begin{array}{l}\text { Phenolic compounds in the extracts ranged from } 3,123 \text { to } 6,644 \mathrm{mg} \text { of catechin } 100 \mathrm{~g}-1 \text {. The extracts showed } \\
\text { good antimicrobial activity against E. coli, Salmonella sp., Pseudomonas aeruginosa, and Staphylococcus } \\
\text { aureus. Mango residues are good sources of phenolic compounds, antimicrobial and antioxidant agents and } \\
\text { should be exploited by the food industry (ARBOS et al., 2013). }\end{array}$ \\
\hline Brazilian mango & $\begin{array}{l}\text { A total of } 12 \text { flavonoids and xanthones were identified in the pulps, peels, and seed kernels with larger amounts } \\
\text { of these compounds in the organically grown Ubá variety. The Ubá mango pulp presented higher antioxidant } \\
\text { activity and the peel and seed kernel extracts showed higher antioxidant activity than the commercial standard } \\
\text { (RIBEIRO et al., 2008). }\end{array}$ \\
\hline
\end{tabular}

of varied matrices such as hamburgers, meatballs, restructured, sausages, and marinated patties. The addition of grape seed and peel extracts (Isabel and Niagara varieties) as natural antioxidants delayed the lipid oxidation of chicken meat (processed, cooked and stored under refrigeration for 14 days), with results comparable to the synthetic antioxidant butylated hydroxytoluene (BHT). The addition of grape extracts combined with vacuum packaging proved to be a good technique to increase the lipid stability of cooked chicken meat (SHIRAHIGUE et al., 2010).

Grape seed and peel extracts (Isabel and Niagara varieties) were as effective as the synthetic antioxidants (BHT and a commercial mixture of sodium erythorbate, citric acid, and sugar) in the prevention of lipid oxidation in the processed products of both raw and cooked chicken, which were stored under frozen conditions for nine months (SELANI et al., 2011). They also improved the oxidative stability of cooked beef (AHN et al., 2002), cooked chicken meat (SHIRAHIGUE et al., 2011), and parts of turkey (LAU \& KING, 2003).

The efficacy of grape polyphenols in delaying the lipid oxidation of fish-based products when stored under frozen conditions was also demonstrated. PAZOS et al. (2005a) verified the antioxidant activity of grape flavonoids obtained from the byproducts of the wine industry in systems containing fish oil and mackerel muscle (Scomber scombrus) and also observed that oligomeric flavonoids have a high potential in inhibiting oxidation in emulsions and in frozen fish muscle. Grape extract and its purified fractions were used in preserving fish 
Table 2 - Agro-industrial residues as natural sources of antioxidants and antimicrobials, the main results of the study, and the technological applications of the wastes - PART II.

\begin{tabular}{|c|c|}
\hline Sources & Main results and applications \\
\hline Peanut skins & $\begin{array}{l}\text { The addition of } 2.5 \% \text { peanut skins rendered an increase of up to } 30 \% \text { in the total polyphenols. Sensory } \\
\text { evaluation tests demonstrated that peanut skin-fortified cookies were well-accepted and the positive effects in } \\
\text { cookies were increased with the increasing polyphenols and potent antioxidant activity (CAMARGO et al., } \\
\text { 2014). }\end{array}$ \\
\hline $\begin{array}{l}\text { Black tea processing } \\
\text { waste }\end{array}$ & $\begin{array}{l}\text { Black tea processing waste (BTPW) can be used as a source of antioxidant and antimicrobial phenolic } \\
\text { compounds (catechins, theaflavins, and gallic acid). BTPW extracts exhibited antimicrobial activity against S. } \\
\text { aureus, Shigella lexneri, and Bacillus cereus; however, the inhibition of Candida albicans was not observed. } \\
\text { BTPW can be used for the development of value-added products with antioxidant and antimicrobial properties } \\
\text { for the applications in food, pharmaceuticals, cosmetics, and agricultural sectors (ÜSTÜNDAG et al., 2016). }\end{array}$ \\
\hline
\end{tabular}

Oils from the seeds of grape, guava, yellow melon, passion fruit, pumpkin, graviola, and tomato

These oils are predominantly unsaturated with a high percentage of linoleic essential fatty acid (38.8-79.4\%), besides significant quantities of tocopherols, phytosterols, and phenolic compounds. Tomato and guava oils showed better results in the antioxidant tests and pumpkin oil had a higher induction period in the oxidative stability test. Results provide information that enables the use of new alternative sources of vegetable oils with biological activities, which can serve as ingredients in food and drugs (SILVA \& JORGE, 2014).

$\begin{aligned} & \text { Apricot by-products were enriched with phenolic compounds by solid-state bioprocessing using filamentous } \\ & \text { fungi. The antioxidant potential increased significantly and the fermentation process with filamentous fungal } \\ & \text { strains not only helped to increase lipid recovery from apricot kernels, but also resulted in oils with better } \\ & \text { quality attibutes, i.e., high linoleic acid content (DULF et al., 2017). }\end{aligned}$
Apricot pomace $\quad \begin{aligned} & \text { Solid-state fermentation helped to achieve higher lipid recovery from plum pomaces and also resulted in oils } \\ & \text { with better quality attibutes (DULF et al., 2016). }\end{aligned}$
Plum pomace
$\begin{aligned} & \text { The antimicrobial activity of tomato waste extracts against S. aureus exhibited moderate correlation with the } \\ & \text { isochlorogenic acid content of the samples; however, no correlation was reported between the antioxidant } \\ & \text { capacity and total phenolic content of the samples. The results suggested that tomato waste represent a reliable } \\ & \text { source of natural bioactive molecules and can serve as functional ingredients in new food formulation (SZABO } \\ & \text { et al., 2019). }\end{aligned}$

meat among species that had high concentrations of polyunsaturated fatty acids (PAZOS et al., 2005b).

The addition of fruit residues (grape seed, orange peel, and tomato paste) was an alternative source of natural antioxidants in enriching ricebased extruded foods (YAGCI \& GOGUS, 2009). Bread formulated with a grape seed extract showed increased antioxidant activity and a decreased amount of carboxymethyl-lysine, a compound formed by the potentially toxic Maillard reaction. The only attribute imparted by the use of grape extract was the color of the bread (PENG et al., 2010). Grape extracts also increased the oxidative stability of the lipid in cheddar cheese (SHAN et al., 2011) and the antioxidant activity in ice creams (HWANG et al., 2009).
The antimicrobial activity of grape extracts has been reported in the literature against a variety of microorganisms such as lactic acid bacteria, foodborne pathogens, and wine spoilage yeasts (JAYAPRAKASHA et al., 2003; BAYDAR et al., 2004; BROWN et al., 2009; KATALINIC et al., 2010; PERUMALLA \& HETTIARACHCHY, 2011; PASTORKOVA et al., 2013). Growth of foodborne pathogens such as Staphylococcus aureus, Salmonella sp., Escherichia coli, Listeria monocytogenes, and Campylobacter sp. were inhibited by grape seed extracts (ROTAVA et al., 2009; SHAN et al., 2011; SILVÁN et al., 2013; FILOCAMO et al., 2015). A flavan-3-ol enriched grape seed extract inhibited the growth of lactic acid bacteria such as Lactobacillus 
Table 3 - Agro-industrial residues as natural sources of antioxidants and antimicrobials, the main results of the study, and the technological applications of the wastes - PART III.

\begin{tabular}{|c|c|}
\hline Sources & Main results and applications \\
\hline Jabuticaba seeds & $\begin{array}{l}\text { The gross jabuticaba seed extract was partially purified and exhibited high antimicrobial potential toward } \\
\text { bacteria. Electrospray ionization coupled with tandem mass spectrometry data showed the presence of } \\
\text { ellagitannins and ellagic acid in the extracts, which are probably responsible for the antimicrobial and } \\
\text { antioxidant activities (HACKE et al., 2016). }\end{array}$ \\
\hline $\begin{array}{l}\text { Apple, pear, tomato, } \\
\text { goldenrod and artichoke } \\
\text { wastes }\end{array}$ & $\begin{array}{l}\text { This study demonstrated the possibility of recovering high amounts of phenolics with antioxidant } \\
\text { properties from fruit and vegetable residuals not only for food but also for cosmetic applications } \\
\text { (PESCHEL et al., 2006). }\end{array}$ \\
\hline $\begin{array}{l}\text { Apple peels, carrot pulp, } \\
\text { white and red grape peels } \\
\text { and red beet peels and } \\
\text { pulp }\end{array}$ & $\begin{array}{l}\text { The thermally processed red grape waste had the highest antimicrobial effect and also antimutagenic } \\
\text { activity toward S. typhimurium. Apple peel, carrot pulp, red and white grape peel and beetroot pulp can be } \\
\text { exploited for their nutrients and antioxidant components and used to add value in food formulations } \\
\text { (VODNAR et al., 2017). }\end{array}$ \\
\hline $\begin{array}{l}\text { Avocado, jackfruit, } \\
\text { longan, mango, and } \\
\text { tamarind seeds }\end{array}$ & $\begin{array}{l}\text { The seeds showed a much higher antioxidant activity and phenolic content than the edible portions. The } \\
\text { contribution of all fruit seed fractions to the total antioxidant activity and phenolic content was always } \\
\qquad>70 \% \text { (SOONG \& BARLOW, 2004). }\end{array}$ \\
\hline $\begin{array}{l}\text { Kinnow peel and seeds, } \\
\text { litchi pericarp and seeds, } \\
\text { grape seeds, and banana } \\
\text { peel }\end{array}$ & $\begin{array}{l}\text { Kinnow peel extract exhibited the highest reducing power and DPPH free radical scavenging activity, } \\
\text { whereas the phenolic content (TPC) of } 37.4 \mathrm{mg} \text { gallic acid equivalents (GAE) g-1 was highest for grape } \\
\text { seed extract. Banana peel extract with a low TPC showed the lowest reducing power, as well as DPPH free } \\
\text { radical scavenging activity among the fruit residues (BABBAR et al., 2011). }\end{array}$ \\
\hline Chokeberry pomace & $\begin{array}{l}\text { The extractable phenolics and total flavonoids increased during fermentation processes. A longer } \\
\text { fermentation period resulted in a greater loss of anthocyanins. The HPLC-MS analysis of phenolic } \\
\text { compounds showed that the amounts of flavonols and cinnamic acids increased while the concentrations of } \\
\text { glycosylated anthocyanins decreased substantially. The present investigation demonstrated that the } \\
\text { fermentation process enriched the chokeberry pomace with phenolic antioxidants and lipids with better } \\
\text { nutritional quality characteristics (DULF et al., 2018). }\end{array}$ \\
\hline Citrus residues & $\begin{array}{l}\text { Linalol is the major component of the leaf essential oil and limonene in the fruit peel essential oil. The } \\
\text { essential oil from leaves showed antimicrobial activities against bacteria but not against fungi. The } \\
\text { essential oil from the fruit peel showed no antimicrobial activity (LOPES et al., 2013). }\end{array}$ \\
\hline Citrus byproducts & $\begin{array}{l}\text { In the agar diffusion assays, the essential oils inhibited all of the tested microorganisms and the major } \\
\text { inhibition zones were detected on Candida utilis. As for the bacteria, the oils showed better inhibition of S. } \\
\text { aureus than that of E. coli and P. aeruginosa. The inhibitory effect of the citrus oils was effective on } \\
\text { Penicillium expansum fungus; except for Cravo-lemon oil, which showed a growth-stimulating effect } \\
\text { (GERHARDT et al., 2012). }\end{array}$ \\
\hline
\end{tabular}

fermentum and L. plantarum (TABASCO et al., 2011), which are the common contaminants of the bioethanol industry process (BASSO et al., 2014). Grape extracts have been reported as more effective against bacteria than yeasts; and consequently, the results obtained with lactic acid bacteria are shown to be very promising for application in the ethanol fuel industry.

\section{Citrus}

Citrus fruits, chiefly, oranges, mandarins, limes, and lemons, are the most produced and consumed fruits in the world (OLIVEIRA et al., 2009). Different citrus fruits have a small edible portion and generate a large amount of residues such as peels and seeds during food processing (MIRABELLA et al., 2014). These residues are the sources of several compounds, mainly, water-soluble sugars, fibers, organic acids, amino acids and proteins, minerals, oils, and lipids. They also contain flavonoids and vitamins (FERNÁNDEZ-LOPEZ et al., 2004). Residues such as dry pulp and molasses, fiber, seeds, and bagasse are the sources of essential oils, pectin, ascorbic acid, and flavonoids (BRADDOCK, 1995; OZAKI et al., 2000; SCHIEBER et al., 2001).

Citrus peels are rich in various nutrients that act as functional and beneficial components, which have wide applications, depending on their composition. These byproducts have several secondary metabolites, such as terpenoids, 
Table 4 - Agro-industrial residues as natural sources of antioxidants and antimicrobials, the main results of the study, and the technological applications of the wastes - PART IV.

\begin{tabular}{|c|c|}
\hline Sources & Main results and applications \\
\hline Winery grape residue & $\begin{array}{l}\text { The grape extracts were effective in promoting oxidative stability when applied at concentrations of } 40 \text { or } 60 \\
\text { mg of GAE kg-1 with results similar to the synthetic antioxidant BHT. The antioxidant effects of the extracts } \\
\text { were highly dependent on the concentration. The addition of winery grape residue to raw and cooked chicken } \\
\text { meat provided a satisfactory protective effect against lipid oxidation in cooked chicken meat stored under } \\
\text { refrigeration (SHIRAHIGUE et al., 2011). }\end{array}$ \\
\hline Winery grape residue & $\begin{array}{l}\text { Winery grape residue extracts were effective in inhibiting the lipid oxidation of raw and cooked chicken meat } \\
\text { with results comparable to synthetic antioxidants. The extracts caused alterations in color and sensory results } \\
\text { of cooked samples. In the sensory evaluation of odor and flavor, the extracts produced satisfactory results, } \\
\text { which did not differ from synthetic antioxidants. The addition of winery grape residue to frozen cooked } \\
\text { chicken meat provided a satisfactory protective effect against lipid oxidation with results comparable to a } \\
\text { synthetic antioxidant (SELANI et al., 2011). }\end{array}$ \\
\hline Grape seeds & $\begin{array}{l}\text { Grape seed extract showed potential inhibition of oxidative rancidity in cooked pork patties in comparison to } \\
\text { current synthetic antioxidants (SASSE et al., 2009). }\end{array}$ \\
\hline $\begin{array}{l}\text { Grape seeds and } \\
\text { bearberry }\end{array}$ & $\begin{array}{l}\text { Grape seed extracts and bearberry decreased the lipid oxidation in raw pork patties after } 9 \text { and } 12 \text { days from } \\
\text { storage. The antioxidant activity of extracts was observed in cooked pork patties demonstrating thermal } \\
\text { stability. Results showed the potential use of health-promoting nutraceuticals in meat and meat products } \\
\text { (CARPENTER et al., 2007). }\end{array}$ \\
\hline Grape seeds & $\begin{array}{l}\text { Monomeric procyanidin was reported to be the major compound at } 48 \% \text { and } 40 \% \text { abundance in acetone: } \\
\text { water: acetic acid (90:9.5:0.5) and methanol: water: acetic acid }(90: 9.5: 0.5) \text { extracts, respectively. It was tested } \\
\text { for antibacterial activity against B. cereus, Bacillus coagulans, Bacillus subtilis, S. aureus, E. coli, and P. } \\
\text { aeruginosa. Gram-positive bacteria and Gram-negative bacteria were completely inhibited at 850-1,000 ppm } \\
\text { and at 1,250-1,500 ppm, respectively (JAYAPRAKASHA et al., 2003). }\end{array}$ \\
\hline Grape seeds & $\begin{array}{l}\text { The supplementation of grape seed extract prior to cooking significantly improved the oxidative stability of } \\
\text { minced turkey meat during heat treatment and storage. The ability of grape seed extract to prevent lipid } \\
\text { oxidation was concentration-dependent. The grape seed extract was very effective in inhibiting lipid oxidation } \\
\text { of cooked turkey meat during chill-storage (MIELNIK et al., 2006). }\end{array}$ \\
\hline $\begin{array}{l}\text { Grape seeds and } \\
\text { peels }\end{array}$ & $\begin{array}{l}\text { The phenolic content }(200 \mathrm{mg} \mathrm{kg}-1) \text { in grape extracts did not have any effect on the conjugated diene } \\
\text { hydroperoxides. After six days, the high antioxidative effect was observed for the secondary oxidation } \\
\text { products in conjugated sunflower oil for peel extract followed by seed extract (SHAKER, 2006). }\end{array}$ \\
\hline
\end{tabular}

carotenoids, coumarins, furanocoumarins, and flavonoids, especially flavonones and polyethoxylated flavones, which are rarely reported in other plants. These compounds protect plants against several biotic and abiotic stresses (AHMAD et al., 2006). They are present in the citrus extracts and citrus oils, and due to their antimicrobial and antioxidant activities, there is a growing interest in their application in several areas of food technology (CHOI et al., 2000; FRIEDMANN et al., 2004; PATIL et al., 2009; ASHOK KUMAR et al., 2011; LIU et al., 2012).

The term 'Essential Oil' is utilized to designate complex mixtures of natural compounds of polar and non-polar natures (MASANGO, 2005). It is a product obtained by the distillation of natural materials, consisting of liquid, volatile, limpid, and colored mixtures of aromatic compounds extracted from herbs, spices, and from food and vegetable wastes (WU et al., 2017). Essential oils originate from the secondary metabolism of plants and consist of a mixture of compounds, mainly monoterpenes, sesquiterpenes, and oxygenated derivatives (alcohols, aldehydes, ester, ethers, ketones, phenols, and oxides). They also contain other volatile compounds, such as phenylpropanoids and substances containing sulfur or nitrogen (BAJPAI et al., 2008; VALERIANO et al., 2012).

Studies have reported the application of natural antimicrobials obtained from citrus essential oils (FISHER \& PHILLIPS, 2008). These products have reported their use in the development of several pharmaceutical preparations due to their antiseptic properties (BISIGNANO \& SAIJA, 2002). GERHARDT et al. (2012) evaluated the varieties of 
bergamot-pokan (Citrus reticulata Blanco), grapefruit (Citrus maxima (Burm.) Merr.), and lemon-bergamot (or lemon-clove, Citrus limonia Osbeck) in the growth inhibition of certain microorganisms, such as E. coli, Enterococcus faecalis, S. aureus, Salmonella enteritidis, and Pseudomonas aeruginosa, and observed that all extracts from these different citrus varieties were able to inhibit the growth and/or inactivate the bacterial action.

The control of certain lactic acidproducing spoilage bacteria in apple and orange juices was effective when citrus essential oils were added in combination with mild heat treatment process (PEDROSA et al., 2019). The lemon essential oil showed a considerable inhibitory effect on food spoilage yeasts, such as Geotrichum candidum, Pichia anomala, Saccharomyces cerevisiae, and Schizosaccharomyces pombe, as an alternative to synthetic preservatives in fruit-or-milk-based acidic products (TSERENNADMID et al., 2011). As indicated for grape extracts, citrus essential oil would be a prospective antimicrobial to be used in the bioethanol industry to control the growth of lactic acid bacteria and spoilage yeasts.

The cytotoxic activity of essential oils is attributed to the presence of phenolic compounds like aldehydes, terpenes, aliphatic alcohols, ketones, acids, and isoflavonoids. The phenolic compounds are thought to be the main compound of these oils responsible for the antibacterial properties, but there are reports of non-phenolic compounds, such as allyl isothiocyanate, that are more effective against Gram-negative bacteria (TURINA et al., 2006). The main characteristic feature of the essential oils is the property of hydrophobicity, which gives them the ability to alter the permeability of the mitochondrial cell membrane, thereby making it more permeable with consequent losses of ions and molecules (CARSON et al., 2002).

\section{Mango}

Mango (Mangifera indica L.) is an important tropical fruit in the world, which is extensively marketed because of vast production, wide distribution, and owing to its health benefits to humans (TORRES-LEON et al., 2016). Besides the excellent texture and flavor, it has a high nutritional value, being a source of vitamin $A$ and $C$ and rich in phenolic compounds (THARANATHAN et al., 2006).

Mango wastes, such as the seed kernel and peel, have high functional and nutritional potential. It is estimated that $35-60 \%$ of the fruit is discarded as wastes after processing (O'SHEA et al., 2012). The mango seed has been reported as a biowaste with a high content of bioactive compounds such as phenolic compounds, carotenoids, and vitamin C (JAHURUL et al., 2015; TORRES-LEON et al., 2016). The major phenolic compounds present in mango are gallic acid, ellagic acid, gallates, gallotannins, condensed tannins, mangiferins, catechin, epicatechin, and benzoic acid. Such compounds present in the seed and bark show greater antioxidant activity than the fruit as such (SOONG \& BARLOW, 2004; RIBEIRO et al., 2008). This antioxidant activity is mainly due to their reducing properties, which play an important role in the neutralization or sequestration of free radicals or chelation of transition metals acting both in the initiation stage as well as in propagation of the oxidative process (SOARES, 2002).

Mango seeds can also be used as a source of natural antimicrobials. Ethanolic extracts of mango seeds exhibited a spectrum of antimicrobial activities and were effective against Gram-negative bacteria (KABUKI et al., 2000). The structure of its active component confirmed it to be a phenolic compound. The antibacterial activity of different mango peel extracts against Gram-positive $S$. aureus and Gram-negative Pseudomonas fluorescens was investigated. Extracts showed varying degrees of antibacterial activities against both organisms. Generally, Gram-positive bacteria are susceptible to natural compounds, while Gram-negative organisms exhibit less sensitivity. The peel from Langra mango variety extracted with $70 \%$ ethanol and $80 \%$ acetone exhibited maximum zone of inhibition against both organisms. The difference in the antimicrobial effects between Gram-positive and Gram-negative bacteria is due to the presence of different cell wall structures. Compounds that can effectively diffuse the lipid bilayer and increase membrane fluidity may be considered as more effective antibacterial agents (KANATT \& CHAWLA, 2017).

\section{Avocado}

Avocado (Persea americana Mill.) is a dicotyledonous plant belonging to the Lauraceae family, a native of Central America and Mexico, and cultivated in almost all tropical and subtropical regions worldwide. The fruits have high nutritional quality; contain high levels of vitamin, minerals, proteins, fibers, and unsaturated fatty acids, which are beneficial to health (TREMOCOLDI et al., 2018). Avocado peels and seeds have high contents of bioactive compounds, such as phenolic acids, condensed tannins, flavonoids (including 
procyanidins and flavonols), hydroxybenzoic and hydroxycinnamic acids (HURTADO-FERNÁNDEZ et al., 2011; DAIUTO et al., 2014; FIGUEROA et al., 2018a, b).

Industrial processing of avocado generates large quantities of agro-industrial byproducts (peel and seed), ranging from $18 \%$ to $23 \%$ of fruit dry weight (WANG et al. 2010). The individual phenolic profiles of hydroethanolic extracts of peels and kernels of avocado variety Hass showed correlation with their antioxidant, antimicrobial, and cytotoxic activities. Avocado byproducts presented a very distinct phenolic profile, with a higher concentration in peels (227.9 $\mathrm{mg} \mathrm{g}^{-1}$ of total phenolic content), mainly of (epi)catechin derivatives (175 $\mathrm{mg} \mathrm{g}^{-1}$ ), followed by chlorogenic derivatives $\left(42.9 \mathrm{mg} \mathrm{g}^{-1}\right.$ ) (MELGAR et al., 2018). The bioactive compounds can also be reported in seeds, such as catechin, protocatechin, epicatechin, and also p-coumaric, caffeic, ferulic, synaptic, p-hydroxybenzoic, vanillic, syringic, and gallic acids (RODRIGUEZ-CARPENA et al., 2011).

Studies have shown the antimicrobial effect of the compounds extracted from avocado seed extract on microorganisms. SALINAS-SALAZAR et al. (2017) have shown a biocidal effect of avocado seed extracts $\left(7.8-15 \mathrm{mg} \mathrm{L}^{-1}\right)$ on L. monocytogenes, suggesting that the effect was due to the increase in permeability of cell membrane. The ethanolic extract of avocado seed had antimicrobial action against L. monocytogenes $\left(375.0 \mu \mathrm{g} \mathrm{L} \mathrm{L}^{-1}\right)$, Staphylococcus epidermidis (354.2 $\left.\mu \mathrm{g} \mathrm{L}^{-1}\right)$ and Zygosaccharomyces bailii $\left(500 \mu \mathrm{g} \mathrm{L}^{-1}\right)$ (CHIA \& DIKES, 2010).

\section{CONCLUSION}

Several low-cost raw materials are available as agro-industrial wastes that are valuable sources of bioactive compounds. The huge variety of compounds produced by plants as secondary metabolites may act as antioxidants and antimicrobials with applications in the food and fermentation industries. Fruit wastes, in particular citrus, avocado, grape, and mango wastes, have been used for the extraction of compounds with biological activities similar to the synthetic compounds that are commonly used. These compounds offer a more natural and safer option to the food industry. The fermentation process involved in the bioethanol production deals with bacterial contaminants that could be combated with these natural antimicrobials; however, their utilization in the context of this industry has not received due attention. A promising field of application emerges from these investigative reports that could relieve the unsustainable use of hazardous chemicals in the bioethanol industry to fight bacterial contamination.

\section{ACKNOWLEDGMENTS}

This study was financed in part by the Coordenação de Aperfeiçoamento de Pessoal de Nível Superior (CAPES), Brasil - finance code 001, including a grant for the first author (PNPD $\left.\mathrm{n}^{\mathrm{o}} 33001014051 \mathrm{P} 7\right)$, and by Fundação de Amparo a Pesquisa do Estado de São Paulo (FAPESP), Brasil (research support $\mathrm{n}^{\circ}$ 2018/19139-2).

\section{DECLARATION OF CONFLICT OF INTERESTS}

The authors declare no conflict of interest. The founding sponsors had no role in the design of the study; in the collection, analyses, or interpretation of data; in the writing of the manuscript, and in the decision to publish the results.

\section{AUTHORS' CONTRIBUTIONS}

All authors contributed equally to this research.

\section{REFERENCES}

ADEGOKE, G.O. et al. Antioxidants, and lipid oxidation in foods - a critical appraisal. Journal of Food Science and Technology, v.35, n.4, p.283-298, 1998.

AHMAD, M.M. et al. Genetic variability to essential oil composition in four citrus fruit species. Pakistan Journal of Botany, v.38, n.2, p.319-324, 2006. Available from: <https:// naturalingredient.org/wp/wp-content/uploads/PJB382319.pdf>. Accessed: Feb. 14, 2020.

AHN, D.U. et al. Packaging and irradiation effects on lipid oxidation and volatiles in pork patties. Journal of Food Science, v.63, n.1, p.15-19, 1998. Available from: <https://doi. org/10.1111/j.1365-2621.1998.tb15665x>. Accessed: Mar. 22, 2019. doi: 10.1111/j.1365-2621.1998.tb15665x.

AHN, J. et al. Antioxidant properties of natural plant extracts containing polyphenolic compounds in cooked ground beef. Journal of Food Science, v.67, p.1364-1369, 2002. Available from: $<$ https://doi.org/10.1111/j.1365-2621.2002.tb10290.x>. Accessed: Sep. 14, 2019. doi: 10.1111/j.1365-2621.2002.tb10290.x.

ALEXANDRINO, A.M. et al. Aproveitamento do resíduo de laranja para produção de enzimas lignocelulolíticas por Pleurotus ostreatus (Jack:Fr). Ciência e Tecnologia de Alimentos, v.27, n.2, p.364-368, 2007. Available from: <http://dx.doi.org/10.1590/ S0101-20612007000200026>. Accessed: Oct. 11, 2019. doi: 10.1590/S0101-20612007000200026.

ALLEN, J.C.; HAMILTON, R.J. Rancidity in foods. London: Blackie Academic, 1994. 290p.

ARAÚJO, M. et al. Phenolic compounds from olive mil waste: health effects, analytical approach and application as food antioxidants. Trends in Food Science and Technology, v.45, 
p.200-211, 2015. Available from: <https://doi.org/10.1016/j. tifs.2015.06.010>. Accessed: Oct. 12, 2019. doi: 10.1016/j. tifs.2015.06.010

ARBOS, A.A. et al. Atividade antimicrobiana, antioxidante e teor de compostos fenólicos em casca e amêndoa de frutos de manga. Revista Ceres, v.60, p.161-165, 2013. Available from: <http:// dx.doi.org/10.1590/S0034-737X2013000200003>. Accessed: Oct. 12, 2019. doi: 10.1590/S0034-737X2013000200003.

ARSHAD, M.S.; BATOOL, S.A. Natural antimicrobials, their sources and food safety. In: KARUNARATNE, D.N. Food additives. London: IntechOpen, 2017. p.87-102. Available from: $<\mathrm{http}: / /$ dx.doi.org/10.5772/intechopen.70197>. Accessed: Oct. 31, 2019. doi: 10.5772/intechopen.70197.

ASHOK KUMAR, K. et al. Antimicrobial activity and phytochemical analysis of citrus fruit peels - utilization of fruit waste. International Journal of Engineering Science and Technology, v.3, n.6, p.54145421, 2011. Available from: <https://pdfs.semanticscholar.org/0d23/ d42295d3f4abd7cd9b121817a06b63a34588.pdf >. Accessed: Feb. $14,2020$.

ATANASOVA-PENICHON, V. et al. Antioxidant secondary metabolites in cereals: potential involvement in resistance to Fusarium and mycotoxin accumulation. Frontiers in Microbiology, v.7, 566, 2016. Available from: <https://doi. org/10.3389/fmicb.2016.00566>. Accessed: Oct. 31, 2019. doi: $10.3389 /$ fmicb.2016.00566

BABBAR, N. et al. Total phenolic content and antioxidant capacity of extracts obtained from six important fruit residues. Food Research International, v.44, p.391-396, 2011. Available from: $<$ https://doi.org/10.1016/j.foodres.2010.10.001>. Accessed: Oct. 02, 2019. doi: 10.1016/j.foodres.2010.10.001.

BAJPAI, V.K. et al. Chemical composition and inhibitory parameters of essential oil and extracts of Nandina domestica Thunb. to control food-borne pathogenic and spoilage. International Journal of Food Microbiology, v.125, n.2, p.117-122, 2008. Available from: $<$ https://doi.org/10.1016/j.ijfoodmicro.2008.03.011>. Accessed: Oct. 02, 2019. doi: 10.1016/j.ijfoodmicro.2008.03.011.

BALASUNDRAM, N. et al. Phenolic compounds in plants agriindustrial by products: antioxidant activity, occurrence, and potential uses. Food Chemistry, v.99, p.191-203, 2006. Available from: $<$ https://doi.org/10.1016/j.foodchem.2005.07.042>. Accessed: Oct. 02, 2019. doi: 10.1016/j.foodchem.2005.07.042.

BASSO, T.O. et al. Homo-and heterofermentative lactobacilli differently affect sugarcane-based fuel ethanol fermentation. Antonie van Leeuwenhoek, v.105, p.169-177, 2014. Available from: <https://doi.org/10.1007/s10482-013-0063-6>. Accessed: Oct. 31, 2019. doi: 10.1007/s10482-013-0063-6.

BAYDAR, N.G. et al. Total phenolic contents and antibacterial activities of grape (Vitis vinifera L.) extracts. Food Control, v.15, n.5, p.335-339, 2004. Available from: <https://doi.org/10.1016/ S0956-7135(03)00083-5>. Accessed: Oct. 31, 2019. doi: 10.1016 S0956-7135(03)00083-5.

BISIGNANO, G.; SAIJA, A. The biological activity of citrus oils. In: DUGO, G.; DI GIACOMO, A. Citrus: the genus Citrus. Boca Raton: CRC Press, 2002. p.602-630.

BRADDOCK, R.J. Byproducts of citrus fruit. Food Technology, v.49, p.74-77, 1995.
BREWER, M.S. Natural antioxidants: sources, compounds, mechanisms of action, and potential applications. Comprehensive Reviews in Food Science and Food Safety, v.10, p.221-247-10, 2011. Available from: $<$ https://doi.org/10.1 111/j.1541-4337.2011.00156.x>. Accessed: Oct. 03, 2019. doi: 10.1111/j.1541-4337.2011.00156.x.

BROWN, J.C. et al. Antibacterial effects of grape extracts on Helicobacter pylori. Applied and Environmental Microbiology, v.75, n.3, p.848-852, 2009. Available from: <https://doi. org/10.1128/AEM.01595-08>. Accessed: Oct. 31, 2019. doi: 10.1128/AEM.01595-08.

BURT, S. Essential oils: their antibacterial properties and potential applications in foods - a review. International Journal of Food Microbiology, v.94, n.3, p.223-53, 2004. Available from: <http:// doi.org/10.1016/j.ijfoodmicro.2004.03.022>. Accessed: Oct. 31 2019. doi: 10.1016/j.ijfoodmicro.2004.03.022.

CAETANO, A.C.S. et al. Extração de antioxidantes de resíduos agroindustriais de acerola. Brazilian Journal of Food Technology, v.12, p.155-160, 2009. Available from: <http://dx.doi.org/10.4260/ BJFT2009800900006>. Accessed: Oct. 03, 2019. doi: 10.4260/ BJFT2009800900006.

CALOMENI, A.V. et al. Characterization of antioxidant and antimicrobial properties of spray-dried extracts from peanut skins. Food and Bioproducts Processing, v.105, p.215-223, 2017. Available from: <http://doi.org/10.1016/j.fbp.2017.08.0011>. Accessed: Oct. 31, 2019. doi: 10.1016/j.fbp.2017.08.0011.

CAMARGO, A.C. et al. Fortification of cookies with peanut skins: effects on the composition, polyphenols, antioxidant properties, and sensory quality. Journal of Agricultural and Food Chemistry, v.62, n.46, p.11228-11235, 2014. Available from: <http://dx.doi. org/10.1021/jf503625p>. Accessed: Oct. 04, 2019. doi: 10.1021/ jf503625p.

CAMARGO, A.C. et al. Opinion on the hurdles and potential health benefits in value-added use of plant food processing byproducts as sources of phenolic compounds. International Journal of Molecular Sciences, v.19, n.11, 3498, 2018. Available from: <http://doi.org/10.3390/ijms19113498>. Accessed: Oct. 31, 2019. doi: $10.3390 /$ ijms 19113498 .

CARBONELL-CAPELLA, J.M. et al. Quality parameters, bioactive compounds and their correlation with antioxidant capacity of commercial fruit-based baby foods. Food Science and Technology International, v.20, n.7, p.479-487, 2013. Available from: <https://doi.org/10.1177/1082013213492523>. Accessed: Oct. 03, 2019. doi: 10.1177/1082013213492523.

CARPENTER, R. et al. Evaluation of the antioxidant potential of grape seed and bearberry extracts in raw and cooked pork. Meat Science, v.76, p.604-610, 2007. Available from: $<$ https://doi. org/10.1016/j.meatsci.2007.01.021>. Accessed: Oct. 03, 2019. doi: 10.1016/j.meatsci.2007.01.021

CARSON, C.F. et al. Mechanism of action of Melaleuca alternifolia (tea tree) oil on Staphylococcus aureus determined by time-kill, lysis, leakage and salt tolerance assays and electron microscopy. Antimicrobial Agents and Chemotherapy, v.46, p.1914:1920, 2002. Available from: <https://doi.org/10.1128/ AAC.46.6.1914-1920.2002>. Acessed: Sep. 27, 2019. doi: 10.1128/AAC.46.6.1914-1920.2002. 
CHIA, T.W.R.; DIKES, G.A. Antimicrobial activity of crude epicarp and seed extracts from mature avocado fruit (Persea americana) of three cultivars. Pharmaceutical Biology, v.48, n.7, p.753-756, 2010. Available from: <https://doi. org/10.3109/13880200903273922>. Acessed: Oct. 31, 2019. doi: $10.3109 / 13880200903273922$

CHOI, H. et al. Radical-scavenging activities of Citrus essential oils and their components: detection using 1,1-diphenyl-2picrylhydrazyl. Journal of Agricultural and Food Chemistry, v.48, p.4156-4161, 2000. Available from: <https://doi.org/10.1021/ jf000227d $>$. Accessed: Oct. 03, 2019. doi: 10.1021/jf000227d.

CORREIA, R.T. et al. Bioactive compounds and phenolic-linked functionality of powdered tropical fruit residues. Food Science and Technology International, v.18, n.6, p.539-547, 2012. Available from: <https://doi.org/10.1177/1082013211433077>. Accessed: Oct. 31, 2019. doi: 10.1177/1082013211433077.

DAIUTO, E.R. et al. Composição química e atividade antioxidante da polpa e resíduos de abacate 'HASS'. Revista Brasileira de Fruticultura, v.36, n.2, p.417-424, 2014. Available from: <http:// dx.doi.org/10.1590/0100-2945-102/13>. Accessed: Oct. 31, 2019. doi: 10.1590/0100-2945-102/13.

DENG, G.F. et al. Potential of fruit wastes as natural resources of bioactive compounds. International Journal of Molecular Sciences, v.13, p.8308-8323, 2012. Available from: <http:// doi.org/10.3390/ijms13078308>. Accessed: Jan. 05, 2020. doi: 10.3390/ijms13078308.

DULF, F.V. et al. Effects of solid-state fermentation with two filamentous fungi on the total phenolic contents, flavonoids, antioxidant activities and lipid fraction of plum fruit (Prunus domestica L.) by-products. Food Chemistry, v.209, p.2736, 2016. Available from: <http://dx.doi.org/10.1016/j. foodchem.2016.04.016>. Accessed: Dec. 18, 2019. doi: 10.1016/j. foodchem.2016.04.016.

DULF, F.V. et al. Phenolic compounds, flavonoids, lipids and antioxidant potential of apricot (Prunus armeniaca L.) pomace fermented by two filamentous fungal strains in solid state system. Chemistry Central Journal, v.40, p.94-102, 2017. Available from: <http://dx.doi.org/10.1186/s13065-017-0323-z>. Accessed: Dec. 18, 2019. doi: 10.1186/s13065-017-0323-z.

DULF, F.V. et al. Liberation and recovery of phenolic antioxidants and lipids in chokeberry (Aronia melanocarpa) pomace by solid-state bioprocessing usind Aspergillus niger and Rhizopus oligosporus strains. LWT - Food Science and Technology, v.87, p.241-249, 2018. Available from: <http://dx.doi.org/10.1016/j. lwt.2017.08.084>. Accessed: Dec. 18, 2019. doi: 10.1016/j. lwt.2017.08.084

DZIEZAK, J.D. Antioxidants - the ultimate answer to oxidation. Food Technology, v.40, p.94-102, 1986.

FERNÁNDEZ-LOPEZ, J. et al. Application of functional citrus byproducts to meat products. Trends in Food Science and Technology, v.15, p.176-185, 2004. Available from: $<$ https://doi. org/10.1016/j.tifs.2003.08.007>. Accessed: Oct. 05, 2019. doi: 10.1016/j.tifs.2003.08.007.

FERRARI, R.A. et al. Caracterização de subprodutos da industrialização do maracujá - aproveitamento das sementes. Revista Brasileira de Fruticultura, v.26, p.101-102-26,
2004. Available from: <http://dx.doi.org/10.1590/S010029452004000100027>. Accessed: Oct. 09, 2019. doi: 10.1590/ S0100-29452004000100027.

FIGUEROA, J.G. et al. Comprehensive characterization of phenolic and other polar compounds in the seed and seed coat of avocado by HPLC-DAD-ESIQTOF- MS. Food Research International, v.105, p.752-763, 2018a. Available from: $<$ https:// doi.org/10.1016/j.foodres.2017.11.082>. Accessed: Oct. 16, 2019. doi: 10.1016/j.foodres.2017.11.082.

FIGUEROA, J.G. et al. Comprehensive identification of bioactive compounds of avocado peel by liquid chromatography coupled to ultra-high-definition accurate-mass Q-TOF. Food Chemistry, v.245, p.707-716, 2018b. Available from: $<$ https://doi. org/10.1016/j.foodchem.2017.12.011>. Accessed: Oct. 16, 2019. doi: $10.1016 /$ j.foodchem.2017.12.011

FILOCAMO, A. et al. In vitro antimicrobial activity and effect on biofilm production of a white grape juice (Vitis vinifera) extract. Evidence-Based Complementary and Alternative Medicine, v.2015, 856243, 2015. Available from: <https:// doi.org/10.1155/2015/856243>. Accessed: Oct. 13, 2019. doi: $10.1155 / 2015 / 856243$.

FISHER, K.; PHILLIPS, C. Potential antimicrobial uses of essential oils in food: is citrus an answer? Trends in Food Science and Technology, v.19, p.156-164, 2008. Available from: $<$ https:// doi.org/10.1016/j.tifs.2007.11.006>. Accessed: Oct. 13, 2019. doi: 10.1016/j.tifs.2007.11.006.

FRIEDMANN, M. et al. Antibacterial activities of plant essential oils and their components against Escherichia coli $\mathrm{O} 157: \mathrm{H} 7$ and Salmonella enterica in apple juice. Journal of Agricultural and Food Chemistry, v.52, p.6042-6048, 2004. Available from: $<$ https://doi.org/10.1021/jf0495340>. Accessed: Sep. 30, 2019. doi: $10.1021 / \mathrm{jf} 0495340$

GERHARDT, C. et al. Aproveitamento da casca de citros na perspectiva de alimentos: prospecção da atividade antibacteriana. Brazilian Journal of Food Technology, v.15, p.11-17, 2012. Available from: <http://dx.doi.org/10.1590/S198167232012005000033>. Accessed: Sep. 03, 2019. doi: 10.1590/ S1981-67232012005000033.

GERSTENMEYER, E. et al. Effect of thermal heating on some lignans in flax seeds, sesame seeds and rye. Food Chemistry, v.138, p.1847-1855, 2013. Available from: <http://doi.org/doi: 10.1016/j.foodchem.2012.11.117>. Accessed: Jan. 05, 2020. doi: 10.1016/j.foodchem.2012.11.117.

HACKE, A.C.M. et al. Jabuticaba (Myrciaria cauliflora) seeds: chemical characterization and extraction of antioxidant and antimicrobial compounds. Journal of Food Science, v.81, n.9, p.C2206-C2217, 2016. Available from: <https://doi. org/10.1111/1750-3841.13405>. Accessed: Sep. 09, 2019. doi: $10.1111 / 1750-3841.13405$.

HE, J.; GIUSTI, M.M. Anthocyanins: natural colorants with health-promoting properties. Annual Review of Food Science and Technology, v.1, p.163-187, 2010. Available from: <https:// doi.org/10.1146/annurev.food.080708.100754>. Accessed: Jan. 05, 2020. doi: 10.1146/annurev.food.080708.100754.

HOLLMAN, P.C.H. et al. Analysis and health effects of flavonoids. Food Chemistry, v.57, p.43-46, 1996. Available from: <https:// 
doi.org/10.1016/0308-8146(96)00065-9>. Accessed: Oct. 01, 2019. doi: 10.1016/0308-8146(96)00065-9.

HOLLMAN, P.C.H., KATAN, M.B. Absorption, metabolism and health effects of dietary flavonoids in man. Biomedicine and Pharmacotherapy, v.51, p.305-310, 1997. Available from: $<$ https://doi.org/10.1016/S0753-3322(97)88045-6>. Accessed: Oct. 09, 2019. doi: 10.1016/S0753-3322(97)88045--6.

HURTADO-FERNÁNDEZ, E. et al. Profiling LC-DAD-ESI-TOF MS method for the determination of phenolic metabolites from avocado (Persea americana). Journal of Agricultural and Food Chemistry, v.9, p.2255-2267, 2011. Available from: $<$ https://doi. org/10.1021/jf104276a >. Accessed: Oct. 09, 2019. doi: 10.1021/ jf104276a.

HWANG, J.Y. et al. Grape wine lees improves the rheological and adds antioxidants properties to ice cream. LWT - Food Science and Technology, v.42, p.312-318, 2009. Available from: $<\mathrm{http}: / /$ dx.doi.org/10.1016/j.1wt.2008.03.008>. Accessed: Oct. 01, 2019. doi: 10.1016/j.1wt.2008.03.008.

JAHURUL, M.H.A. et al. Mango (Mangifera indica L.) byproducts and their valuable components: a review. Food Chemistry, v.183, p.173-180, 2015. Available from: $<$ https://doi. org/10.1016/j.bjp.2018.06.008>. Accessed: Oct. 31, 2019. doi: 10.1016/j.bjp.2018.06.008.

JAYAPRAKASHA, G.K. et al. Antioxidant activity of grape seed (Vitis vinifera) extracts peroxidation models in vitro. Food Chemistry, v.73, p.285-290, 2001. Available from: <http://dx.doi. org/10.1016/S0308-8146(00)00298-3>. Accessed: Oct. 01, 2019. doi: $10.1016 / \mathrm{S} 0308-8146(00) 00298-3$.

JAYAPRAKASHA, G.K. et al. Antibacterial and antioxidant activities of grape (Vitis vinifera) seed extracts. Food Research International, v.36, n. 2, p.117-122, 2003. Available from: $<$ https://doi.org/10.1016/S0963-9969(02)00116-3>. Accessed: Sep. 09, 2019. doi: 10.1016/S0963-9969(02)00116-3.

KABUKI, T. et al. Characterization of novel antimicrobial compounds from mango (Mangifera indica L.) kernel seeds. Food Chemistry, v.71, p.61-66, 2000. Available from: $<$ https://doi. org/10.1016/S0308-8146(00)00126-6>. Accessed: Sep. 09, 2019. doi: 10.1016/S0308-8146(00)00126-6.

KANATT, S.R.; CHAWLA, S.P. Shelf life extension of chicken packed in active film developed with mango peel extract. Journal of Food Safety, v.38, n.1, e12385, 2017. Available from: < https://doi.org/10.1111/ jfs. 12385>. Accessed: Sep. 30, 2019. doi: 10.1111/jfs. 12385.

KATALINIC, V. et al. Polyphenolic profile, antioxidant properties and antimicrobial activity of grape skin extracts of 14 Vitis vinifera varieties grown in Dalmatia (Croatia). Food Chemistry, v.119, n.2, p.715-723, 2010. Available from: <https://doi.org/10.1016/j. foodchem.2009.07.019>. Accessed: Sep. 30, 2019. doi: 10.1016/j. foodchem.2009.07.019.

KHAMENEH, B. et al. Review on plant antimicrobials: a mechanistic viewpoint. Antimicrobial Resistance \& Infection Control, v.8, 118, 2019. Available from: <http://doi.org/10.1186/ s13756-019-0559-6>. Accessed: Oct. 31, 2019. doi:10.1186/s13756-019-0559-6.

KHANDUJA, K.L.; BHARDWAJ, A. Stable free radical scavenging and anti peroxidative properties of resveratrol in vitro compared with some others bioflavonoids. Indian Journal of Biochemistry and Biophysics, v.40, p.416-422, 2003. Available from: $<$ https://pdfs.semanticscholar.org/c45e/5d3a15137b0c29e9d 69409e7b823f35f0466.pdf $>$. Accessed: Feb. 14, 2020.

KOBORI, C.N.; JORGE, N. Caracterização dos óleos de algumas sementes de frutas como aproveitamento de resíduos industriais. Ciência e Agrotecnologia, v.29, p.1008-1014, 2005. Avaiable from: <http://dx.doi.org/10.1590/S1413-70542005000500014>. Accessed: Oct. 07,2019. doi: 10.1590/S1413-70542005000500014.

LAU, D.W.; KING, A.J. Pre-and post-mortem use of grape seed extract in dark poultry meat to inhibit development of thiobarbituric acid reactive substances. Journal of Agricultural and Food Chemistry, v.51, p.1602-1607-51, 2003. Available from: <https://doi.org/10.1021/jf020740m>. Accessed: Sep. 09, 2019. doi: $10.1021 / \mathrm{jf0} 20740 \mathrm{~m}$.

LIU, L. et al. Structure-activity relationship of Citrus polymethoxylated flavones and their inhibitory effects on Aspergillus niger. Journal of Agricultural and Food Chemistry, v.60, p.4336-4341, 2012. Available from: <http://dx doi. org/10.1021/jf3012163>. Accessed: Oct. 06, 2019. doi: 10.1021/ jf3012163.

LOPES, L.T.A. et al. Composição química e atividade antimicrobiana do óleo essencial e anatomia foliar e caulinar de Citrus limettioides Tanaka (Rutaceae). Revista de Ciências Farmacêuticas Básica e Aplicada, v.34, n.4, p.503-511, 2013. Available from: <https://pdfs.semanticscholar.org/725c/9ece97d3 117c5d2e9b5b79cbfb10dd419f20.pdf $>$. Accessed: Feb. 14, 2020.

MARQUES, T.R. et al. Characterization of phenolic compounds, antioxidant and antibacterial potential the extract of acerola bagasse flour. Acta Scientiarum. Technology, v.39, n.2, p.143-148, 2017. Available from: <https://doi.org/10.4025/actascitechnol. v39i2.28410>. Acessed: Oct. 05, 2019. doi: 10.4025/actascitechnol. v39i2.28410.

MASANGO, P. Cleaner production of essential oils by steam distillation. Journal of Cleaner Production, v.13, p.833-839, 2005. Available from: <https://doi.org/10.1016/j.jclepro.2004.02.039>. Acessed: Oct. 05, 2019. doi: 10.1016/j.jclepro.2004.02.039.

MAXCHEIX, J.J. et al. The main phenolic of fruits. In: Fruit phenolics. Boca Raton : CRC Press, 1990. p.1-98.

MELGAR, B. et al. Bioactive characterization of Persea americana Mill. by-products: a rich source of inherent antioxidants. Industrial Crops \& Products, v.111, p.212:218, 2018. Available from: $<$ http://dx.doi.org/10.1016/j.indcrop.2017.10.024>. Accessed: Oct. 06, 2019. doi: 10.1016/j.indcrop.2017.10.024.

MIDDLETON, E.; KANDASWAMI, C. Potential healthpromoting properties of citrus flavonoids. Food Technology, v.48, p.115-119, 1994.

MIELNIK, M.B. et al. Grape seed extract as antioxidant in cooked, cold stored turkey meat. LWT - Food Science and Technology, v.39, p.191-198, 2006. Available from: <http://dx.doi. org/10.1016/j.lwt.2005.02.003>. Accessed: Oct. 06, 2019. doi: 10.1016/j.lwt.2005.02.003.

MIRABELLA, N. et al. Current options for the valorization of food manufacturing waste: a review. Journal of Cleaner Production, v.65, p.28-41, 2014. Available from: <https://doi.org/10.1016/j. 
jclepro.2013.10.051>. Accessed: Oct. 09, 2019. doi: 10.1016/j. jclepro.2013.10.051.

MISI, S.N.; FORSTER, C.F. Semi-continuous anaerobic co-digestion of agro-waste. Environmental Technology, v.23, p.445-451, 2002. Available from: <http://dx.doi. org/10.1080/09593332508618405>. Accessed: Oct. 06, 2019. doi: $10.1080 / 09593332508618405$.

MOURE, A. et al. Natural antioxidants from residual sources. Food Chemistry, v.72, p.145-171, 2001. Available from: $<$ https:// doi.org/10.1016/S0308-8146(00)00223-5>. Accessed: Oct. 01, 2019. doi: 10.1016/S0308-8146(00)00223-5.

OLIVEIRA, A.C. et al. Fontes naturais de antioxidantes. Química Nova, v.32, p.689-702, 2009. Available from: <http://dx.doi. org/10.1590/S0100-40422009000300013>. Accessed: Aug. 29, 2019. doi: 10.1590/S0100-40422009000300013.

OLIVEIRA, L.L. et al. Health promoting and sensory properties of phenolic compounds in food. Revista Ceres, v.61, p.764 779, 2014. Available from: <http://dx.doi.org/10.1590/0034737X201461000002>. Accessed: Jan. 05, 2020. doi: 10.1590/ S0100-40422009010.1590/0034-737X201461000002.

O'SHEA, N. et al. Dietary fibre and phytochemical characteristics of fruit and vegetable byproducts and their recent applications as novel ingredients in food products. Innovative Food Science \& Emerging Technologies, v.16, p.1-10, 2012. Available from: $<\mathrm{https}$ ://doi.org/10.1016/j.ifset.2012.06.002>. Accessed: Aug. 29, 2019. doi: $10.1016 /$ j.ifset.2012.06.002.

OZAKI, Y. et al. Limonoid glucosides of Satsuma mandarin (Citrus unshiu Marcov.) and its processing products. In: BERHOW, M.A. et al. Citrus limonoids: functional chemical in agriculture and food. Washington: ACS Symposium Series, 2000. p.107-119. Avaiable from: <https://doi.org/10.1021/bk-2000-0758.ch008>. Accessed: Aug. 23, 2019. doi: 10.1021/bk-2000-0758.ch008.

OZSOY, N. et al. Implications for degenerative disorder: antioxidant activity, total phenols, flavonoids, ascorbic acid, betacarotene and beta-tocopherol in Aloe vera. Oxidative Medicine and Cell Longevity, v.2, n.2, p.99-106, 2009. Available from: $<\mathrm{http} / / /$ downloads.hindawi.com/journals/omcl/2009/315091.pdf $>$. Accessed: Feb. 14, 2020.

PASTORKOVA, E. et al. Growth inhibitory effect of grape phenolic against wine spoilage yeasts and acetic acid bacteria. International Journal of Food Microbiology, v.161, p.209-213, 2013. Available from: $\quad<$ http://dx.doi.org/10.1016/j.ijfoodmicro.2012.12.018> Accessed: Oct. 01, 2019. doi: 10.1016/j.ijfoodmicro.2012.12.018.

PATIL, J.R. et al. Bioactive compounds from Mexican lime (Citrus aurantifolia) juice induce apoptosis in human pancreatic cells. Journal of Agricultural and Food Chemistry, v.57, p.10933-10942, 2009. Available from: <https://doi.org/10.1021/ jf901718u>. Accessed: August, 25, 2019. doi: 10.1021/ jf901718u.

PAZOS, M. et al. Preservation of the endogenous antioxidant system of fish muscle by grape polyphenols during frozen storage. European Food Research and Technology, v.220, n.5-6, p.514519, 2005a. Available from: $<$ https://doi.org/10.1007/s00217-0041113-0>. Accessed: August, 26, 2019. doi: 10.1007/s00217-004$1113-0$.
PAZOS, M. et al. Activity of grape polyphenol as inhibitors of the oxidation of fish lipids and frozen fish muscle. Food Chemistry, v.92, p.547-557, 2005b. Available from: <https://doi.org/10.1016/j. foodchem.2004.07.036>. Accessed: August, 30, 2019. doi: 10.1016/j.foodchem.2004.07.036.

PEDROSA, G.T.S. et al. Control of autochthonous spoilage lactic acid bacteria in apple and orange juices by sensorially accepted doses of Citrus spp. essential oils combined with mild heat treatments. Journal of Food Science, v.84, n.4, p.848-858, 2019. Available from: <https://doi.org/10.1111/1750-3841-14474>. Accessed: August, 26, 2019. doi: 10.1111/1750-3841-14474.

PENG, X. et al. The effects of grape seed extract fortification on the antioxidant activity and quality attributes of bread. Food Chemistry, v.119, p.49-53, 2010. Available from: $<\mathrm{http}: / / \mathrm{dx}$.doi. org/10.1016/j.foodchem.2009.05.083>. Accessed: August, 26, 2019. doi: 10.1016/j.foodchem.2009.05.083.

PERUMALLA, A.S.; HETTIARACHCHY, N. Green tea and grape seed extracts - potential applications in food safety and quality. Food Research International, v.44, p.827-839, 2011. Available from: $<\mathrm{http} / / \mathrm{dx}$.doi.org/10.1016/j.foodres.2011.01.022> Accessed: Oct. 01, 2019. doi: 10.1016/j.foodres.2011.01.022.

PESCHEL, W. et al. An industrial approach in the search of natural antioxidants from vegetable and fruit wastes. Food Chemistry, v.97, p.137-150, 2006. Available from: <http://dx.doi. org/10.1016/j.foodchem.2005.03.033>. Accessed: Oct. 08, 2019. doi: 10.1016/j.foodchem.2005.03.033.

POKORNY, J. Natural antioxidants for food use. Trends in Food Science and Technology, v.2, p.223-227, 1991. Available from: $<$ https://doi.org/10.1016/0924-2244(91)90695-F>. Accessed: Oct. 08, 2019. doi: 10.1016/0924-2244(91)90695-F.

RABABAH, T.M. et al. Total phenolics and antioxidant activities of Fenugreek, Green Tea, Black Tea, Grape Seed, Ginger, Rosemary, Gotu Kola, and Ginkgo Extracts, Vitamin E and tertButylhydroquinone. Journal of Agricultural and Food Chemistry, v.52, p.5183-5186, 2004. Available from: <https://doi.org10.1021/ jf049645z $>$. Accessed: Oct. 05, 2019. doi: 10.1021/jf049645z.

RIBEIRO, S.M.R. et al. Phenolic compounds and antioxidant capacity of Brazilian mango (Mangifera indica L.) varieties. Food Chemistry, v.110, p.620-626, 2008. Available from: <http:// dx.doi.org/10.1016/j.foodchem.2008.02.067>. Accessed: Aug. 20, 2019. doi: $10.1016 /$ j.foodchem.2008.02.067.

RICE-EVANS, C. et al. Structure-antioxidant activity relationships of flavonoids and phenolic acids. Free Radical Biology and Medicine, v.20, n.7, p.933-956, 1996. Available from: <https:// doi.org/10.1016/0891-5849(95)02227-9>. Accessed: August 05, 2019. doi: 10.1016/0891-5849(95)02227-9.

ROCHA, F.D. et al. Produtos naturais de algas marinhas e seu potencial antioxidante. Revista Brasileira de Farmacognisia, v.17, p.631-639, 2007. Available from: <http://dx.doi.org/10.1590/ S0102-695X2007000400024>. Accessed: Jul. 25, 2019. doi: $10.1590 / \mathrm{S} 0102-695 \times 2007000400024$.

RODRIGUES, C. et al. A new alternative to produce gibberellic acid by solid state fermentation. Brazilian Archives of Biology and Technology, v.52, p.181-188, 2009. Available from: <http:// dx.doi.org/10.1590/S1516-89132009000700023>. Accessed: Oct. 01, 2019. doi: 10.1590/S1516-89132009000700023. 
RODRIGUEZ-CARPENA, J.G. et al. Avocado (Persea americana Mill.) phenolic, in vitro antioxidant and antimicrobial activities, and inhibition of lipid and protein oxidation in porcine patties. Journal of Agricultural and Food Chemistry, v.59, p.56255635, 2011. Available from: <https://doi.org/10.1021/jf1048832>. Accessed: Oct. 01, 2019. doi:10.1021/jf1048832.

ROTAVA, R. et al. Atividade antibacteriana, antioxidante e tanante de subprodutos da uva. Ciência Rural, v.39, n.3, p.941944, 2009. Available from: <http://dx.doi.org/10.1590/S1010384782009000300051>. Accessed: Oct. 01, 2019. doi: 10.1590/ S10103-84782009000300051.

SALINAS-SALAZAR, C. et al. Inhibitory activity of avocado seed fatty acid derivates (acetogenins) against Listeria monocytogenes. Journal of Food Science, v.82, p.134-144, 2017. Available from: $<\mathrm{http}: / / \mathrm{dx}$.doi.org/10.1111/1750-3841.13553> Accessed: Oct. 01, 2019. doi:10.1111/1750-3841.13553.

SALMINEN, J.P.; KARONEN, M. Chemical ecology of tannins and other phenolics: we need a change in approach. Functional Ecology, v.25, p.325-338, 2011. Available from: $<$ https://doi.org/ 10.1111/j.1365-2435.2010.01826>. Accessed: Jan. 05, 2020. doi: $10.1111 / \mathrm{j} .1365-2435.2010 .01826$.

SASSE, A. et al. Effect of natural and synthetic antioxidant on oxidative stability of cooked, frozen pork patties. Journal of Food Science, v.74, p.S30-S35, 2009. Available from: <https://doi org/10.1111/j.1750-3841.2008.00979x. Accessed: Oct. 02, 2019. doi: $10.1111 / \mathrm{j} .1750-3841.2008 .00979 \mathrm{x}$.

SCHIEBER, A. et al. Byproducts of plant food processing as a source of functional compounds - recent developments. Trends in Food Science and Technology, v.12, p.401-413, 2001. Available from: <https://doi.org/10.1016/S0924-2244(02)00012-2>. Accessed: Oct. 01, 2019. doi: 10.1016/S0924-2244(02)00012-2.

SCHULER, P. Natural antioxidants exploited commercially. In: HUDSON, B.J.F. Food antioxidants. Dordrecht : Elsevier Science Publishers, 1990. p.99-170. Available from: <https:// link.springer.com/content/pdf/10.1007\%2F978-94-009-0753-9_4. pdf>. Accessed: Feb. 14, 2020.

SELANI, M.M. et al. Wine industry residues extracts as natural antioxidants in raw and cooked chicken meat during frozen storage. Meat Science, v.88, p.397-403, 2011. Available from: $<$ https://doi. org/10.1016/j.meatsci.2011.01.017>. Accessed: August 30, 2019. doi: 10.1016/j.meatsci.2011.01.017.

SELANI, M.M. et al .Physicochemical, functional and antioxidant properties of tropical fruits co-products. Plant Food Human and Nutrition, v.71, p.137-144, 2016. Available from: http://dx.doi. org/10.1007/s11130-016-0531-z. Accessed: Oct. 01, 2019. doi: 10.1007/s11130-016-0531-z.

SERRANO-LEÓN, D. et al. Chitosan active films containing agro-industrial residue extracts for shelf life extension of chicken restructured product. Food Research International, v.108, p.93-100, 2018. Available from: <https://doi.org/10.1016/j. foodres.2018.03.031>. Accessed: Oct. 12, 2019. doi: 10.1016/j. foodres.2018.03.031.

SHAHIDI, F.; AMBIGAIPALAN, P. Phenolics and polyphenolics in food, beverages and spices: antioxidant activity and health effects - A review. Journal of Functional Foods, v. 18, p.820-897, 2015. Available from: http://dx.doi.org/10.1016/j.jff.2015.06.018. Accessed: Oct. 01, 2019. doi: 10.1016/j.jff.2015.06.018.
SHAKER, E.S. Antioxidative effect of extracts from red grape seed and peel on lipid oxidation in oils of sunflower. LWT - Food Science and Technology, v.39, p.883-892, 2006. Available from: $<$ https://doi.org/10.1016/j.lwt.2005.06.004>. Accessed: Aug. 30, 2019. doi: 10.1016/j.lwt.2005.06.004.

SHAN, B. et al. Potential application of spice and herbs extracts as natural preservatives in cheese. Journal of Medicinal Food, v.3, p.284-290, 2011. Available from: <http://dx.doi.org/10.1089/ jmf.2010.0009>. Accessed: Oct., 01 2019. doi: 10.1089/ jmf.2010.0009.

SHI, J. et al. Polyphenolics in grape seeds - biochemistry and functionality. Journal of Medicinal Food, v.6, p.291-299, 2003. Available from: <https://doi.org/10.1089/109662003772519831>. Accessed: Oct. 02, 2019. doi: 10.1089/109662003772519831.

SHIRAHIGUE, L.D. et al. Wine industry residue as antioxidant in cooked chicken meat. International Journal of Food Science and Technology, v.45, p.863-870, 2010. Available from: $<$ https://doi. org/10.1111/j.1365-2621.2010.02201.x>. Accessed: Oct. 04, 2019. doi: $10.1111 / j .1365-2621.2010 .02201 . x$.

SHIRAHIGUE, L.D. et al. Winery grape-residue extract: effects on quality and attributes of cooked chicken meat. Food Science and Biotechnology, v.20, p.1257-1264, 2011. Available from: <https:// doi.org/10.1007/s10068-011-0173-8>. Accessed: Oct. 04, 2019. doi: $10.1007 / \mathrm{s} 10068-011-0173-8$.

SILVA, A.C.; JORGE, N. Bioactive compounds of the lipid fractions of agro-industrial waste. Food Research International, v.66, p.493-500, 2014. Available from: <http://dx.doi.org/10.1016/j. foodres.2014.10.025>. Accessed: Oct., 08, 2019. doi: 10.1016/j. foodres.2014.10.025.

SILVÁN, J.M. et al. Antibacterial activity of grape seed extract and its fractions against Campylobacter spp. Food Control, v.29, p.25-31, 2013. Available from: <https://doi.org/10.1016/j. foodcont.2012.05.063>. Accessed: Oct. 01, 2019. doi: 10.1016/j. foodcont.2012.05.063.

SOARES, S.E. Ácidos fenólicos como antioxidantes. Revista de Nutrição, v.15, p.71-81, 2002. Available from: <http://dx.doi. org/10.1590/S1415-52732002000100008>. Accessed: Oct., 01 2019. doi: $10.1590 / \mathrm{S} 1415-52732002000100008$.

SOONG, Y.Y.; BARLOW, P.J. Antioxidant activity and phenolic content of select fruit seeds. Food Chemistry, v.88, p.411-417, 2004. Available from: <http://dx.doi.org/10.1016/j. foodchem.2004.02.003>. Accessed: Sep. 08, 2019. doi: 10.1016/j. foodchem.2004.02.003.

SOQUETTA, M.B. et al. Green technologies for the extraction of bioactive compounds in fruits and vegetables. CyTA - Journal of Food, v.16, n.1, p.400-412, 2018. Available from: <https://doi.org/ 10.1080/19476337.2017.1411978>. Accessed: Nov. 01, 2019. doi: $10.1080 / 19476337.2017 .1411978$.

SPANOS, G.A.; WROLSTAD, R.E. Phenolic of apple, pear, and white grape juices and their changes with processing and storage - a review. Journal of Agricultural and Food Chemistry, v.40, p.1478-1487, 1992. Available from: <http://dx.doi.org/10.1021/ jf00021a002>. Accessed: Sep. 30, 2019. doi: 10.1021/jf00021a002.

SZABO, K. et al. Antimicrobial and antioxidant properties of tomato processing byproducts and their correlation with the biochemical composition. LWT - Food Science and Technology, 
v.116, p.108558, 2019. Available from: <https://doi.org/10.1016/j. lwt.2019.108558>. Accessed: Dec. 18, 2019. doi: 10.1016/j. lwt.2019.108558.

TABASCO, R. et al. Effect of grape polyphenols on lactic acid bacteria and bifidobacteria growth: resistance and metabolism. Food Microbiology, v.28, p.1345-1352, 2011. Available from: $<$ https://doi.org/10.1016/j.fm.2011.06.005>. Accessed: Oct. 01, 2019. doi: $10.1016 / \mathrm{j} . \mathrm{fm} .2011 .06 .005$.

TAJKARIMI, M.M. et al. Antimicrobial herb and spice compounds in food. Food Control, v.21, p.1199-1218, 2010. Available from: $<\mathrm{https} / / /$ doi.org/10.1016/j.foodcont.2010.02.003>. Accessed: Oct. 01, 2019. doi: 10.1016/j.foodcont.2010.02.003.

THARANATHAN, R.N. et al. Mango (Mangifera indica L.), "The King of Fruits" - an overview. Food Reviews International, v.22, p.95-123, 2006. Available from: $<$ https://doi org/10.1080/87559120600574493>. Accessed: Oct. 01, 2019. doi: $10.1080 / 87559120600574493$.

TORRES-LEON, C. et al. Mango seed: functional and nutritional properties. Trends in Food Science and Technology, v.55, p.109-117, 2016. Available from: <https://doi.org/10.1016/j. tifs.2016.06.009>. Accessed: Oct. 01, 2019. doi: 10.1016/j. tifs.2016.06.009

TREMOCOLDI, R. et al. Exploration of avocado by-products as natural sources of bioative compounds. PLoS ONE, v.13, e0192577, 2018. Available from: https://doi.org/10.1371/journal. pone.0192577. Accessed: Oct. 01, 2019. doi: 10.1371/journal. pone. 0192577

TSERENNADMID, R. et al. Anti yeast activities of some essencial oils in growth medium, fruit juice and milk. International Journal of Food Microbiology, v.144, p.480-486, 2011. Available from: <https://doi.org/ DOI: 10.1016/j.ijfoodmicro.2010.11.004>. Accessed: Oct. 01, 2019. doi: 10.1016/j.ijfoodmicro.2010.11.004.

TURINA, A.V. et al. Natural terpenes: self-assembly and membrane partitioning. Biophysical Chemistry, v.101, p.113-122, 2006 Available from: <https://doi.org/10.1016/j.bpc.2006.02.007> Accessed: Oct. 01, 2019. doi: 10.1016/j.bpc.2006.02.007.

ÜSTÜNDAG, O.G. et al. Black tea processing waste as a source of antioxidant and antimicrobial phenolic compounds. European Food Research and Tecnology, v.242, p.1523-1532, 2016. Available from: <https://doi.org/10.1007/s00217-016-2653-9>. Accessed: Oct. 01, 2019. doi: 10.1007/s00217-016-2653-9.

VALERIANO, C. Atividade antimicrobiana de óleos essenciais em bactérias patogênicas de origem alimentar. Revista Brasileira de Plantas Medicinais, v.14, n.1, p.5767, 2012. Available from: <http://dx.doi.org/10.1590/S151605722012000100009>. Accessed: Sep., 14, 2019. doi: 10.1590/ S1516-05722012000100009.
VIEIRA, P.A.F. et al. Caracterização química do resíduo do processamento agroindustrial da manga (Mangifera indica $\mathrm{L}$.) var. Ubá. Alimentos e Nutrição, v.2, n.4, p.617-623, 2009. Available from: $\quad<$ http://serv-bib.fcfar.unesp.br/seer/index.php/alimentos/ article/viewFile/1240/867\&gt>. Accessed: Feb. 14, 2020.

VODNAR, D.C. et al. Identification of the bioactive compounds and antioxidant, antimutagenic and antimicrobial activities of thermally processed agro-industrial waste. Food Chemistry, v.231, p.131-140, 2017. Available from: <http://dx.doi.org/10.1016/j. foodchem.2017.03.131>. Accessed: Dec. 18, 2019. doi: 10.1016/j. foodchem.2017.03.131.

WANG, W. et al. Antioxidant capacities, procyanidins and pigments in avocados of different strains and cultivars. Food Chemistry, v.122, p.1193-1198, 2010. Available from: <https:// doi.org/10.1016/j.foodchem.2010.03.114>. Accessed: Oct. 01, 2019. doi: 10.1016/j.foodchem.2010.03.114.

WEBER, H.A. et al. Comparison of proanthocyanidins in commercial antioxidants: grape seed and pine bark extracts. Journal of Agricultural Food and Chemistry, v.55, p.148156, 2007. Available from: <https://doi.org/10.1021/jf063150n>. Accessed: Oct. 06, 2019. doi: 10.1021/jf063150n.

WU, F. et al. Electrofluidic pretreatment for enhancing essential oil extraction from citrus fruit peel waste. Journal of Cleaner Production, v.159, p.85-94, 2017. Available from: $<$ https://doi. org/10.1016/j.jclepro.2017.05.010>. Accessed: Oct. 05, 2019. doi: 10.1016/j.jclepro.2017.05.010.

XU, D.P. et al. Natural antioxidants in foods and medicinal plants: extraction, assessment and resources. International Journal of Molecular Sciences, v.18, p.96, 2017. Available from: <https:// doi.org/10.3390/ijms18010096>. Accessed: Jan. 05, 2020. doi: 10.3390/ijms 18010096

$\mathrm{XU}$, G. et al. Composition and distribution of phenolic acids in Ponkan (Citrus poonensis Hort. Ex. Tanaka) and Huyou (Citrus paradise Macf. Changshanhuyou) during maturity. Journal of Food Compositions and Analysis, v.21, p.382-389, 2008. Available from: <https://doi.org/10.1016/j.jfca.2008.03.003>. Accessed: Oct. 05, 2019. doi: 10.1016/j.jfca.2008.03.003.

YAGCI, S.; GOGUS, F. Effect of incorporation of various food byproducts on some nutritional properties of rice-based extruded foods. Food Science and Technology International, v.15, p.571-581, 2009. Available from: <https://doi. org/10.1177/1082013209353078>. Accessed: Oct. 05, 2019. doi: $10.1177 / 1082013209353078$.

ZHANG, H.; TSAO, R. Dietary polyphenols, oxidative stress and antioxidante and anti-inflammatory effects. Current Opinion in Food Science, v.8, p.33-42, 2016. Available from: $<$ https://doi. org/10.1016/j.cofs.2016.02.002>. Accessed: Oct. 05, 2019. doi: 10.1016/j.cofs.2016.02.002 